Journal of Economic, Business and Accounting (COSTING)

Volume 2 Nomor 1, Juli-Desember 2018

e-ISSN : 2597-5234

https://doi.org/10.31539/costing.v2i1.460

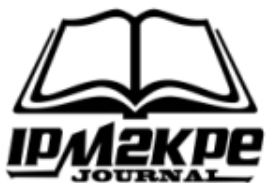

\title{
PENGARUH KOMUNIKASI DAN KEMAMPUAN KERJA TERHADAP KINERJA PEGAWAI
}

\section{THE EFFECT OF COMMUNICATION AND EMPLOYMENT ABILITY ON ERFORMANCE EMPLOYEES}

\author{
Fitria \\ Sekolah Tinggi Ilmu Ekonomi Musi Rawas Lubuklinggau \\ fitriahidayat492@gmail.com
}

\begin{abstract}
Organizational Performance is as a whole organizational effectiveness to meet the determined needs of each group that is related to systemic efforts and to increase the organization's ability to continuously achieve their needs effectively. This research was conducted to determine the Effect of Communication and Work Ability on Employee Performance at the Office of Food Crops, Plantations and Forestry, Lubuklinggau City. In this study used a three item variable questionnaire method, namely communication questionnaire (X1), work ability (X2) and employee performance variable (Y). The population and samples used in this study were 73 official employees of food crops, plantations and forestry in the city of Lubuklinggau. The data analysis technique used is the Analysis of Multiple Linear Regression. The results showed that there was a significant effect between communication and work ability on employee performance at the Lubuklinggau City Food, Plantation and Forestry Service Office. Furthermore communication (X1), and work ability (X2) contributes an influence of $64.9 \%$ on employee performance $(Y)$. While the remaining $35.1 \%$ is influenced by other variables.
\end{abstract}

Keywords: Communication, Work Ability and Performance

\begin{abstract}
ABSTRAK
Kinerja Organisasi adalah sebagai efektivitas organisasi secara menyeluruh untuk memenuhi kebutuhan yang ditetapkan dari setiap kelompok yang berkenaaan dengan usaha - usaha yang sistemik dan meningkatkan kemampuan organisasi secara terus menerus yang mencapai kebutuhannya secara efektif . Penelitian ini dilakukan untuk mengetahui Pengaruh Komunikasi dan Kemampuan Kerja Terhadap Kinerja Pegawai Pada Dinas Tanaman Pangan, Perkebunan dan Kehutanan Kota Lubuklinggau. Dalam penelitian ini digunakan metode kuisioner tiga item variabel yaitu kuisioner komunikasi $\left(\mathrm{X}_{1}\right)$, kemampuan kerja $\left(\mathrm{X}_{2}\right)$ dan variabel kinerja pegawai $(\mathrm{Y})$. Populasi dan sampel yang digunakan dalam penelitian ini adalah pegawai dinas tanaman pangan, perkebunan dan kehutanan kota Lubuklinggau yang berjumlah 73 orang. Teknik analisis data yang digunakan adalah Analisis Regresi Linier Berganda. Hasil penelitian menunjukkan terdapat pengaruh signifikan antara komunikasi dan kemampuan kerja terhadap kinerja pegawai pada Dinas Tanaman Pangan, Perkebunan dan Kehutanan Kota Lubuklinggau. Selanjutnya komunikasi $\left(\mathrm{X}_{1}\right)$, dan kemampuan kerja $\left(\mathrm{X}_{2}\right)$ memberikan sumbangan pengaruh sebesar 64,9\% terhadap kinerja pegawai (Y). Sedangkan sisanya sebesar 35,1\% dipengaruhi oleh variabel yang lain.
\end{abstract}

Kata kunci : Komunikasi, Kemampuan Kerja dan Kinerja 


\section{PENDAHULUAN}

Dalam suatu organisasi diperlukan suatu sistem yang dapat menunjang kinerja organisasi tersebut. Komunikasi yang baik dan kemampuan kerja yang tinggi mendukung kinerja pegawai. Manusia selalu terlibat dalam aktivitas kegiatan "komunikasi". Terjadinya komunikasi merupakan konsekuensi dari akibat adanya interaksi di antara sesama manusia (human interactions), atau hubungan yang bersifat sosial (social relations), karena kenyataannya yang paling banyak terlibat dalam proses komunikasi adalah manusia. Umumnya jika seseorang mengerti tentang sesuatu yang dinyatakan orang lain kepadanya, maka komunikasi sedang berlangsung. Dengan kata lain, hubungan antara komunikator dan komunikan sudah komunikatif. Sebaliknya, jika tidak ada kesamaan pemahaman atau komunikan tidak mengerti apa yang disampaikan komunikator, maka kornunikasi tidak terjadi.

Dalam melaksanakan pekerjaannya, pegawai tidak lepas dari komunikasi dengan sesama rekan sekerja, dengan atasan dan dengan bawahan. Komunikasi yang baik dapat menjadi sarana yang tepat dalam meningkatkan. kinerja pegawai. Melalui komunikasi, pegawai dapat meminta petunjuk kepada atasan mengenai pelaksanaan kerja. Melalui komunikasi juga pegawai dapat saling bekerja sama satu sama lain. Komunikasi dalam organisasi menunjukkan keharmonisan hubungan antara atasan dan bawahan serta dengan orang-orang pada tingkat yang setara. Bentuk komunikasi yang berlangsung dapat berupa komunikasi formal maupun non - formal.

Selain komunikasi yang baik faktor yang mendukung kinerja adalah kemampuan kerja. Kemampuan kerja yang baik akan memberikan efek yang baik terhadap kinerja pegawai. Kemampuan kerja adalah keterampilan dan pengetahuan yang dimiliki seseorang dalam bekerja. Semakin baik keterampilan dan pengetahuan pegawai, akan semakin baik pula kemampuan kerjanya sehingga dapat memberikan kontribusi yang besar terhadap organisasi atau instansi.

Kinerja adalah hasil yang diperoleh oleh suatu organisasi baik organiasi itu bersifat profit oriented dan non profit oriented yang dihasilkan selama periode waktu (Fahmi, 2011). Kinerja Organisasi adalah sebagai efektivitas organisasi secara menyeluruh untuk memenuhi kebutuhan yang ditetapkan dari setiap kelompok yang berkenaaan dengan usaha - usaha yang sistemik dan meningkatkan kemampuan organisasi secara terus menerus yang mencapai kebutuhannya secara efektif (Fahmi, 2011). Kinerja pegawai tinggi akan membawa keberhasilan instansi.

$$
\text { Dinas Tanaman Pangan, }
$$

Perkebunan dan Kehutanan Kota Lubuklinggau mempunyai tugas melaksanakan kewenangan otonomi daerah dalam bidang Pertanian dalam rangka pelaksanaan tugas desentralisasi. Dalam menyelenggarakan tugas sebagaimana yang dimaksud pada peraturan daerah ini, Dinas Tanaman Pangan, Perkebunan dan Kehutanan Kota Lubuklinggau mempunyai Fungsi : 1). Perumusan kebijakan teknis dibidang Pertanian sesuai dengan lingkup tugasnya, 2) Pemberian perizinan dan pelaksanaan teknis Dinas Tanaman Pangan, Perkebunan dan Kehutanan Kota Lubuklinggau dalam lingkungannya

Berdasarkan pengamatan awal peneliti pada Dinas Tamanan Pangan, 
Perkebunan dan Kehutanan Kota Lubuklinggau. Pertama, kurangnya pemahaman terhadap komunikasi antar pegawai, perubahan sikap pegawai mengakibatkan komunikasi yang terjalin kurang baik, kurang adanya hubungan komunikasi yang kondusif, artinya pegawai tampak takut bila berkomunikasi dengan pimpinan/atasan sehingga membuat kinerja pegawai lamban. Kemudian kemampuan kerja belum optimal karena kurangnya keterampilan dan pengetahuan pegawai mengakibatkan kemampuan pegawai dalam menyelesaikan pekerjaannya lambat, masih kurangnya pengalaman kerja sebagian pegawai sehingga kemampuan kerjanya belum optimal, belum adanya penilaian kemampuan kerja sehingga antara pegawai yang rajin dengan yang malas perlakuannya sama.

Adanya perbedaan tujuan yang ingin dicapai pegawai, belum tercapainya standar kerja yang baik, belum adanya umpan balik dalam mengukur kemajuan kinerja, standar kinerja dan pencapaian tujuan, kurang lengkapnya sarana dan prasarana, kompetensi pegawai masih kurang, peluang untuk maju masih kecil.

\section{Komunikasi}

Komunikasi adalah proses penyampaian dan pertukaran informaasi sekurang-kurangnya antara dua pihak yang berperan sebagai pengirim (sender) dan penerima (receiver) dengan menggunakan berbagai media yang ada (Daryanto,2013).

Menurut

Rivai

Komunikasi adalah pengiriman dan penerimaan pesan atau berita antara dua orang atau lebih sehingga pesan dimaksud dapat dipahami. Komunikasi juga sebagai proses pemindahan pengertian dalam bentuk gagasan atau informasi dari seseorang kepada orang lain. Selain itu komunikasi diartikan sebagai proses penyampaian informasi atau pengiriman dari seseorang kepada orang lain.

Komunikasi adalah usaha
mendorong
menginterprestasikan pendapat seperti apa yang dikehendaki oleh orang yang mempunyai pendapatan tersebut. Komunikasi merupakan cara menyampaikan gagasan, fakta pikiran, perasaan dan nilai kepada orang lain. Pelaksanaannya selalu melibatkan dua pihak, pengirim (komunikator) dan pihak penerima (komunikan). Menurut Effendy (2006), kalau dua orang terlibat dalam komunikasi, misalnya dalam bentuk percakapan, maka komunikasi akan terjadi atau berlangsung selama ada kesamaan makna mengenai apa yang dipercakapkan. Kesamaan bahasa yang dipergunakan dalam percakapan itu belum tentu menimbulkan kesamaan makna. Dengan lain perkataan, mengerti bahasanya saja belum tentu mengerti makna yang dibawakan oleh bahasa itu.

Menurut Rivai (2012) terdapat delapan unsur pokok didalam proses komunikasi, sebagai berikut:

1. Pengirim atau sumber adalah orang yang mempunyai ide untuk mengadakan komunikasi.

2. Encoding adalah menerjemahkan informasi menjadi serangkaian symbol untuk komunikasi.

3. Massage (pesan) adalah informasi yang sudah disandikan dikirimkan oleh pengirim kepada penerima.

4. Channel (saluran) adalah media komunikasi formal antara seorang pengirim dan seorang penerima.

5. Receiver (penerima) adalah individu yang menanggapi pesan dari pengirim. 
6. Decoding (pengartian) adalah interpretasi suatu pesan menjadi informasi yang berarti.

7. Noice (gangguan) adalah factor yang menimbulkan gangguan, kebingungan terhadap komunikasi.

8. Umpan balik adalah balikan dari proses komunikasi sebagai suatu reaksi terhadap informasi yang disampaikan oleh pengirim.

Beberapa indikator komunikasi

ialah:

1. Pemahaman

Ialah kemampuan memahami pesan secara cermat sebagaimana dimaksudkan oleh komunikator. Tujuan dari komunikasi adalah terjadinya pengertian bersama, dan untuk sampai pada tujuan itu, maka seorang komunikator maupun komunikan harus sama-sama saling mengerti fungsinya masing-masing. Komunikator mampu menyampaikan pesan sedangkan komunikan mampu menerima pesan yang disampaikan oleh komunikator.

2. Kesenangan

Apabila proses komunikasi itu selain berhasil menyampaikan informasi, juga dapat berlangsung dalam suasana yang menyenangkan ke dua belah pihak.. Suasana yang lebih rilex dan menyenangkan akan lebih enak untuk berinteraksi bila dibandingkan dengan suasana yang tegang. Karena komunikasi bersifat fleksibel. Dengan adanya suasana semacam itu, maka akan timbul kesan yang menarik.

3. Pengaruh pada sikap

Tujuan berkomunikasi adalah untuk mempengaruhi sikap. Jika dengan berkomunikasi dengan orang lain, kemudian terjadi perubahan pada perilakunya, maka komunikasi yang terjadi adalah efektif, dan jika tidak ada perubahan pada sikap seseorang, maka komunikasi tersebut tidaklah efektif.

4. Hubungan yang makin baik

Bahwa dalam proses komunikasi yang efektif secara tidak sengaja meningkatkan kadar hubungan interpersonal. Seringkali jika orang telah memiliki persepsi yang sama, kemiripan karakter, cocok, dengan sendirinya hubungan akan terjadi dengan baik.

5. Tindakan. Komunikasi akan efektif jika kedua belah pihak setelah berkomunikasi terdapat adanya sebuah tindakan. Alexis Tan mengemukakan bahwa .Perlu ada daya tarik dengan similarity (kesamaan), familiarity (keakraban) dan proximity (kesukaan). Seseorang biasanya akan cenderung lebih tertarik dengan orang lain karena memiliki faktor kesamaan (sama hobi, sama sifat), keakraban (keluarga, teman karib), dan kesukaan. Dengan kondisi seperti itu orang tidak merasa sungkan untuk berbicara, yakni menceritakan masalah hidupnya secara jujur tanpa adanya kecanggungan berkomunikasi dintara kedunya. Jika sudah demikian, maka antara satu dengan yang lainnya akan saling mempengaruhi dan dengan sendirinya komunikasi akan berlangsung secara efektif. Komunikasi efektif menuntut kepekaan seseorang dalam situasi dan kondisi yang ada, bahkan telah banyak kegagalan organisasi dikaitkan dengan komunikasi yang buruk. Masalah yang paling sulit dalam komunikasi adalah bagaimana cara mendapatkan perhatian dari para pendengar untuk memastikan bahwa mereka mendengarkan. 


\section{Kemampuan Kerja}

Kemampuan seorang individu untuk terus menjalankan usaha dalam menjalaniberbagai macam tugas hingga berhasil yang bisa dikerjakan oleh seseorang. Keseluruhan kemampuan individual personil pada hakikatnya dibentuk oleh sifat-sifat dan kemampuan-kemampuan yang dikemukakan oleh Winardi (2007) bahwa salah satu akibat langsung dari sifat kemampuan yang harus dimiliki oleh setiap organisator harus terus memupuk "inisiatif". Sedangkan Lowser dan Poter mendefinisikan Kemampuan sebagai karakteristik individual seperti intelegensia, manual skill, traits yang merupakan kekuatan potensial seseorang untuk berbuat dan sifatnya stabil.

Sumber daya manusia yang memiliki kemampuan tinggi di dalam suatu organisasi secara universal adalah memiliki kemampuan mengelola bidang administrasi dan penguasaan bahasa untuk bergaul dan berhubungan dengan manusia untuk mengantisipasi kompetisi global. Kemampuan yang dimiliki seseorang akan membuatnya berbeda dengan yang mempunyai kemampuan rata-rata atau standar saja. Secara psikologis, kemampuan pegawai terdiri dari kemampuan potensi dan reality artinya pegawai yang memiiki kemampuan di atas rata-rata dengan pendidikan, pengetahuan, yang memadai dan memiliki sifat-sifat tersebut di atas untuk menjalankan pekerjaan yang terampil dalam mengerjakan pekerjaan sehari-hari maka ia akan lebih mudah menjalankan sesuatu usaha hingga berhasil untuk mencapai prestasi yang diharapkan. Oleh karena itu, pegawai ditempatkan pada pekerjaan sesuai dengan keahliannya.

Kemampuan keseluruhan seorang individu pada dasarnya terdiri atas dua kelompok faktor :
1. Kemampuan

Intelektual

(Intellectual ability).

Kemampuan intelektual adalah kemampuan yang dibutuhkan untuk melakukan berbagai aktivitas mental-berpikir, menalar dan memecahkan masalah. Individu dalam sebagian besar masyarakat menempatkan kecerdasan sebagai tolok ukur dan kecerdasan itu dilihat dari tingkat pendidikan yang semakin tinggi.

2. Kemampuan fisik (physical abilities) Kemampuan fisik adalah kemampuan melakukan tugas-tugas yang menuntut stamina, ketrampilan, kekuatan dan karakteristik serupa. Kemampuan individual dipengaruhi oleh bakat, minat dan faktor kepribadian orang tersebut. Bakat dan minat tersebut pada umumnya diasah dalam pendidikan formal sehari-hari di dalam masyarakat. Sehingga dapat digunakan dalam menyelesaikan pekerjaan dengan baik. Pada umumnya kemampuan individu diperlihatkan dalam kecerdasan intelektual dan pendidikan.

Dalam penelitian ini indikatorindikator kemampuan difokuskan pada teori yang dikemukakan oleh Winardi (2002) yang terdiri dari dimensi-dimensi berikut ini:

1. Keterampilan (Skill). Keterampilan adalah keterampilan dan kecakapan pegawai sebagai akumulasi dari bakat dan kepribadian yang dimilikinya. Indikator Skill meliputi: mampu menyelesaikan tugas tepat pada waktunya, kreatif, inovatif, dan memiliki kemampuan untuk menghitung dengan cepat dan mengoperasikan komputer.

2. Pengetahuan (Knowledge). Pengetahuan adalah pengetahuan yang dimiliki sebagai hasil pendidikan, pengalaman, dan pelatihan di bidang kerjanya. 
Indikator knowledge meliputi: latar belakang pendidikan yang sesuai dengan bidang kerjanya dan sering mengikuti pelatihan di bidangnya.

3. Pengalaman Kerja (Work Experience). Pengalaman kerja adalah pengalaman kerja yang dimiliki pegawai pada Dinas Tanaman Pangan, Perkebunan dan Kehutanan Kota Lubuklinggau. Indikator pengalaman kerja meliputi : Menguasai pekerjaan dengan baik, frekuensi kepindahan tempat kerja tinggi.

\section{Kinerja}

Pengertian kinerja dalam organisasi merupakan jawaban dari berhasil atau tidaknya tujuan organisasi yang telah ditetapkan. Para atasan sering tidak memperhatikan kecuali sudah amat buruk atau segala sesuatu jadi serba salah. Terlalu sering manajer tidak mengetahui betapa buruknya kinerja telah merosot sehingga instansi menghadapi krisis yang serius.

Kinerja adalah hasil yang diperoleh oleh suatu organisasi baik organisasi tersebut bersifat profit oriented dan non profit oriented yang dihasilkan selama satu periode tertentu. Secara lebih lebih tegas Amstrong dan Baron dalam Fahmi (2012) Kinerja merupakan hasil yang mempunyai hubungan kuat dengan tujuan strategis organisasi, kepuasan konsumen dan memberikan kontribusi ekonomi. Lebih jauh Indra Bastian menyatakan bahwa kinerja adalah gambaran mengenai tingkat pencapaian pelaksanaan suatu kegiatan /program/kebijaksanaan dalam mewujudkan sasaran, tujuan, misi dan visi organisasi yang tertuang dalam perumusan skema strategis (strategic planning) suatu organisasi (Fahmi, 2011).

Menurut Kirkpatrick dalam Wibowo (2012), terdapat delapan karakteristik yang membuat suatu standar kinerja efektif, yaitu sebagai berikut:

1. Standar didasarkan pada pekerjaan.

2. Standar dapat dicapai.

3. Standar dapat dipahami.

4. Standar disepakati.

5. Standar itu spesifik dan sedapat mungkin terukur.

6. Standar berorientasi pada waktu.

7. Standar harus tertulis.

8. Standar dapat berubah.

Indikator kinerja pegawai menurut Wibowo (2012) yaitu sebagai berikut :

\section{Tujuan}

Tujuan merupakan keadaan yang berbeda yang secara aktif dicari oleh seorang individu atau organisasi untuk dicapai. Pengertian tersebut mengandung makna bahwa tujuan bukanlah merupakan suatu persyaratan, juga bukan merupakan suatu keinginan. Tujuan merupakan suatu keadaan yang lebih baik yang ingin dicapai dimasa yang akan datang.

2. Standar

Standar mempunyai arti penting karena memberitahukan kapan suatu tujuan dapat diselesaikan. Standar merupakan suatu ukuran apakah tujuan yang diinginkan dapat dicapai. Tanpa standar, tidak dapat diketahui kapan suatu tujuan tercapai.

3. Umpan Balik

Umpan balik merupakan masukan yang dipergunakan untuk mengukur kemajuan kinerja, standar kinerja, dan pencapaian tujuan. Dengan umpan balik dilakukan evaluasi terhadap kinerja dan sebagai hasilnya dapat dilakukan perbaikan kinerja.

4. Alat atau Sarana

Alat atau sarana merupakan sumber daya yang dpata dipergunakan untuk membantu menyelesaikan 
tujuan dengan sukses. Alat atau sarana merupakan faktor penunjang untuk pencapaian tujuan.

5. Kompetensi

Kompetensi merupakan persyaratan utama dalam kinerja. Kompetensi merupakan kemampuan yang dimiliki oleh seseorang untuk menjalankan pekerjaan yang diberikan kepadanya dengan baik.

6. Motif

Motif merupakan alasan atau pendorong bagi seseorang untuk melakukan sesuatu.

7. Peluang

Pekerja perlu mendapatkan kesempatan untuk menujukkan prestasi kerjanya.Terdapat dua faktor yang menyumbangkan pada adanya kekurangan kesempatan untuk berprestasi yaitu ketersediaan waktu dan kemampuan untuk memenuhi syarat.

\section{Kerangka Pemikiran}

Kerangka pemikiran dalam penelitian ini adalah :

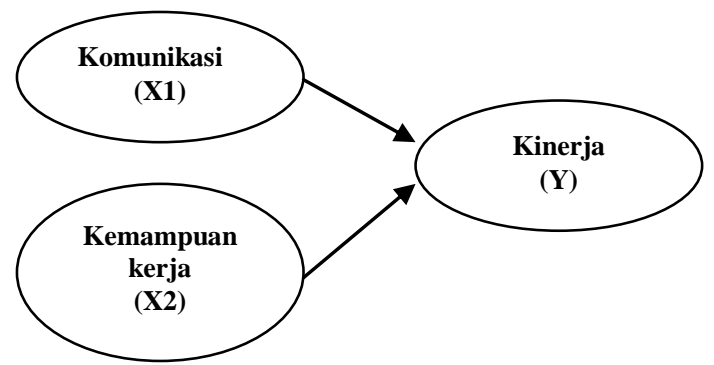

Gambar 1 Kerangka Pemikiran

\section{METODE PENELITIAN}

\section{Lokasi Penelitian}

Lokasi yang dijadikan tempat penelitian ini adalah Dinas Tanaman Pangan, Perkebunan dan Kehutanan Kota Lubuklinggau yang beralamat di Jln. Letkol Sukirno KM. 0,5 Kelurahan Air Kuti, Kecamatan Lubuklinggau Timur I Kota Lubuklinggau.

\section{Populasi dan Sampel}

Populasi adalah wilayah generalisasi yang terdiri atas obyek/subyek yang mempunyai kuantitas dan karekteristik tetentu yang ditetapkan oleh peneliti untuk dipelajari dan kemudian ditarik kesimpulannya (Sugiyono, 2014). Adapun populasi dalam penelitian ini adalah pegawai dinas tanaman pangan, perkebunan dan kehutanan kota Lubuklinggau yang berjumlah 73 orang.

Sampel adalah sebagian dari jumlah dan karateristik yang dimiliki oleh populasi tersebut (Sugiyono, 2014). Teknik penentuan sampel dalam penelitian ini adalah dengan menggunakan sampel jenuh. Sampel jenuh adalah teknik penentuan sampel apabila semua anggota populasi digunakan sebagai sampel. Jadi sampel yang digunakan dalam penelitian ini sebanyak 73 orang responden.

\section{Teknik Pengumpulan Data}

Teknik pengumpulan data yang akan dipergunakan dalam penelitian ini adalah :

1. Observasi

Pengumpulan data dengan cara melakukan pengamatan langsung terhadap semua kegiatan yang dilakukan instansi yang akan diteliti.

2. Kuisioner

Pengumpulan data dengan cara membagikan kuisioner kepada responden dalam hal ini adalah pegawai Dinas Tanaman Pangan, Perkebunan dan Kehutanan Kota Lubuklinggau. Kuisioner tersebut diisi dan dijawab kemudian dikembalikan kepada peneliti.

3. Dokumentasi

Dengan cara mencatat keterangan dan dokumen yang resmi. Tekhnik ini digunakan dalam rangka mendukung data yang diperoleh baik melalui observasi maupun kuesioner. 


\section{Uji Validitas dan Reliabilitas Uji Validitas}

Validitas adalah suatu ukuran yang menujukkan tingkat - tingkat kevalidan atau kesahihan sesuatu instrumen. Suatu instrumen yang valid atau sahih mempunyai validitas tinggi. Sebaliknya, instrumen yang kurang valid berarti memiliki validitas rendah (Arikunto, 2006).

Untuk menghitung korelasi pada uji validitas menggunakan korelasi item total. Menurut Sugiono (2014:188) dengan rumus sebagai berikut:

$$
r_{x y}=\frac{\sum X Y}{\sqrt{\Sigma X^{2} Y 2}}
$$

Keterangan :

$r_{x y} \quad=$ Koefisien Korelasi

$N \quad=$ Banyaknya Sampel

$\sum X \quad=$ Jumlah skor keseluruhan untuk item pertanyaan

$\Sigma Y \quad=$ Jumlah skor keseluruhan untuk semua item pertanyaan

\section{Uji Reliabilitas}

Reliabilitas menunjuk pada suatu pengertian bahwa suatu instrumen cukup dapat dipercaya untuk digunakan sebagai alat pengumpul data karena instrumen tersebut sudah baik. Instrumen yang baik tidak akan bersifat tendensius mengarahkan responden untuk memilih jawaban - jawaban tertentu. Instrumen yang sudah dapat dipercaya, yang reliabel akan menghasilkan data yang dapat dipercaya juga (Arikunto, 2006).

Pengujian reliabilitas kuesioner pada penelitian ini peneliti menggunakan metode Alpha Cronbach (a) menurut Sugiyono (2014:177) dengan rumus sebagai berikut:

$$
R=\alpha=R=\frac{N}{N-1}\left(\frac{S^{2}\left(1-\Sigma S_{i}^{2}\right.}{S^{2}}\right)
$$

Keterangan :

$\alpha=$ Koefisien Reliabilitas Alpha

Cronbach
$S^{2}=$ Varians skor keseluruhan

$S_{i}^{2}=$ Varians masing-masing item

\section{Uji Statistik}

\section{Analisis Regresi Linear Berganda}

Model analisa yang di gunakan peneliti dalam permasalahan yang ada dalam penelitian ini adalah untuk membuktikan ada atau tidaknya hubungan fungsional atau hubungan kuasal antara dua variabel bebas atau lebih dengan satu variabel terikat.

$$
\mathrm{Y}=\mathrm{a}+\mathrm{b}_{1} \mathrm{X}_{1}+\mathrm{b}_{2} \mathrm{X}_{2}
$$

Dimana :

$$
\begin{aligned}
& \mathrm{Y}=\text { Produktivitas Kerja } \\
& \mathrm{X}_{1}=\text { Kompensasi } \\
& \mathrm{X}_{2}=\text { Keselamatan Kerja } \\
& \mathrm{a}=\text { Titik Potong } \\
& \mathrm{b}_{1}, \mathrm{~b}_{2}=\text { Koefisien Regresi }
\end{aligned}
$$

\section{Koefisien Determinasi $\left(\mathbf{R}^{2}\right)$}

Analisis regresi berganda adalah meramalkan bagaimana keadaan naik turunnya variabel dependen, bila dua atau lebih variabel independen sebagai faktor predicator dimanipulasi (dinaik turunkan nilainya) (Sugiyono, 2014). Koefisien determinasi $\left(\mathrm{R}^{2}\right)$ pada intinya mengukur seberapa jauh kemampuan model dalam menerangkan variasi variabel bebas (dependen). Nilai koefisien determinasi adalah di antara nol dan satu. Nilai $\mathrm{R}^{2}$ yang kecil berarti kemampuan variabel-variabel bebas dalam menjelaskan variasi variabel terikat amat terbatas. Nilai $\mathrm{R}^{2}$ yang mendekati satu berarti variabelvariabel bebas memberikan hampir semua informasi yang dibutuhkan untuk memprediksi variasi variabel terikat.

Formulasi persamaan uji korelasi ganda adalah sebagai berikut:

$\sqrt{\frac{\left(r y x_{1}\right)^{2}+\left(r y x_{2}\right)^{2}-2 \cdot\left(r x y_{1}\right) \cdot\left(r y x_{2}\right) \cdot\left(r x_{1} x_{2}\right)}{1-\left(r x_{1} x_{2}\right)}}$

Dimana : 
Ry.X1, $\mathrm{X} 2$ : korelasi variabel $\mathrm{X}_{1}$ dengan $\mathrm{X}_{2}$ secara bersama-sama

ryx $_{1} \quad$ : korelasi sederhana antara $X_{1}$ dengan $\mathrm{Y}$

ryx $_{2}$ : korelasi sederhana antara $X_{2}$ dengan Y

$\mathrm{rx}_{1} \mathrm{x}_{2}:$ korelasi sederhana antara $\mathrm{X}_{1}$ dengan $\mathrm{X}_{2}$

\section{Uji F}

Uji $\mathrm{F}$ dilakukan untuk menguji signifikansi dengan membandingkan $F_{\text {hitung dengan }} F_{\text {tabel }}$ (Riduwan dan Sunarto, 2009:110).

Rumus :

$$
\mathrm{F}_{\text {hitung }}=\frac{R^{2}(n-m-1)}{m\left(1-R^{2}\right)}
$$

Dimana :

$\mathrm{R}^{2} \quad$ : Nilai Regresi

$\mathrm{m}$ : Jumlah variabel bebas

$\mathrm{n}$ : Jumlah responden

Jika :

- $F_{\text {hitung }} \geq F_{\text {tabel }}$, maka tolak Ho artinya signifikan

- $F_{\text {hitung }} \leq F_{\text {tabel}}$, maka terima Ho artinya tidak signifikan

Pengujian dengan uji $F$ variasinya adalah dengan membandingkan $\mathrm{F}_{\text {hitung }}\left(\mathrm{F}_{\mathrm{h}}\right)$ dengan $F_{\text {tabel }}\left(F_{t}\right)$ pada $\alpha=0,05$ apabila hasil perhitungannya menunjukkan :

1. $\mathrm{F}_{\mathrm{h}}>\mathrm{F}_{\mathrm{t}}$, maka $\mathrm{H}_{0}$ ditolak dan $\mathrm{h}_{\mathrm{a}}$ diterima

Artinya variasi dari model regresi berhasil menerangkan variasi variabel bebas secara keseluruhan, sejauh mana pengaruhnya terhadap variabel tidak bebas (variabel terikat).

2. $\mathrm{F}_{\mathrm{h}}<\mathrm{F}_{\mathrm{t}}$, maka $\mathrm{H}_{0}$ diterima dan $\mathrm{H}_{\mathrm{a}}$ ditolak

Artinya variasi dari model regresi tidak berhasil menerangkan variasi variabel bebas secara keseluruhan, sejauh mana pengaruhnya terhadap variabel tidak bebas (variabel terikat).
HASIL DAN PEMBAHASAN Hasil Uji Validitas dan Reliabilitas

Tabel 1

Hasil Uji Validitas Variabel Komunikasi $\left(\mathbf{X}_{1}\right)$

\begin{tabular}{ccccc}
\hline No & Item & $\mathrm{r}_{\text {hitung }}$ & $\begin{array}{c}\mathrm{r}_{\text {tabel }} \\
=0,05 \\
\mathrm{n}=20\end{array}$ & Ket \\
\hline 1. & Pertanyaan 1 & 0,710 & 0,444 & Valid \\
\hline 2. & Pertanyaan 2 & 0,764 & 0,444 & Valid \\
\hline 3. & Pertanyaan 3 & 0,617 & 0,444 & Valid \\
\hline 4. & Pertanyaan 4 & 0,452 & 0,444 & Valid \\
\hline 5. & Pertanyaan 5 & 0,705 & 0,444 & Valid \\
\hline 6. & Pertanyaan 6 & 0,639 & 0,444 & Valid \\
\hline 7. & Pertanyaan 7 & 0,603 & 0,444 & Valid \\
\hline 8. & Pertanyaan 8 & 0,543 & 0,444 & Valid \\
\hline 9. & Pertanyaan 9 & 0,675 & 0,444 & Valid \\
\hline 10. & Pertanyaan 10 & 0,509 & 0,444 & Valid \\
\hline & & & &
\end{tabular}

Tabel 2

Tabel 2 Hasil Uji Validitas Variabel Kemampuan Kerja $\left(\mathbf{X}_{2}\right)$

\begin{tabular}{ccccc}
\hline No & Item & $\mathrm{r}_{\text {hitung }}$ & $\begin{array}{c}\mathrm{r}_{\text {tabel }} \\
\mathrm{n}=0,05 \\
\mathrm{n}=20\end{array}$ & Ket \\
\hline 1. & Pertanyaan 1 & 0,602 & 0,444 & Valid \\
\hline 2. & Pertanyaan 2 & 0,664 & 0,444 & Valid \\
\hline 3. & Pertanyaan 3 & 0,620 & 0,444 & Valid \\
\hline 4. & Pertanyaan 4 & 0,572 & 0,444 & Valid \\
\hline 5. & Pertanyaan 5 & 0,667 & 0,444 & Valid \\
\hline 6. & Pertanyaan 6 & 0,500 & 0,444 & Valid \\
\hline 7. & Pertanyaan 7 & 0,732 & 0,444 & Valid \\
\hline 8. & Pertanyaan 8 & 0,664 & 0,444 & Valid \\
\hline 9. & Pertanyaan 9 & 0,620 & 0,444 & Valid \\
\hline 10. & Pertanyaan 10 & 0,771 & 0,444 & Valid \\
\hline Sumbrana
\end{tabular}

Sumber : Data Olahan (2018)

Tabel 3

Hasil Uji Validitas

Variabel Kinerja Pegawai (Y)

\begin{tabular}{ccccc}
\hline No & Item & $\mathrm{r}_{\text {hitung }}$ & $\begin{array}{c}\mathrm{r}_{\text {tabel }} \\
\mathrm{n}=0,05 \\
\mathrm{n}=20\end{array}$ & Ket \\
\hline 1. & Pertanyaan 1 & 0,732 & 0,444 & Valid \\
\hline 2. & Pertanyaan 2 & 0,702 & 0,444 & Valid \\
\hline 3. & Pertanyaan 3 & 0,594 & 0,444 & Valid \\
\hline 4. & Pertanyaan 4 & 0,543 & 0,444 & Valid \\
\hline 5. & Pertanyaan 5 & 0,726 & 0,444 & Valid \\
\hline 6. & Pertanyaan 6 & 0,596 & 0,444 & Valid \\
\hline 7. & Pertanyaan 7 & 0,475 & 0,444 & Valid \\
\hline 8. & Pertanyaan 8 & 0,570 & 0,444 & Valid \\
\hline 9. & Pertanyaan 9 & 0,726 & 0,444 & Valid \\
\hline 10. & Pertanyaan 10 & 0,700 & 0,444 & Valid \\
\hline & & & &
\end{tabular}


Dari tabel diatas dapat dilihat bahwa hasil pengujian validitas instrumen menunjukkan bahwa seluruh pernyataan valid karena nilai $r_{\text {hitung }}$ lebih besar dari nilai $r_{\text {tabel }}$ dan bernilai positif.

\section{Tabel 4}

Hasil Uji Reabiilitas

\begin{tabular}{cccc}
\hline $\begin{array}{c}\text { Variabel } \\
\text { Penelitian }\end{array}$ & $\begin{array}{c}\text { Nilai } \\
\text { Cronbach's } \\
\text { Alpha }\end{array}$ & Nilai $\mathrm{r}_{\text {tabel }}$ & Ket \\
\hline $\begin{array}{c}\text { Komunikasi } \\
\left(\mathrm{X}_{1}\right)\end{array}$ & 0,885 & 0,444 & Reliabel \\
\hline $\begin{array}{c}\text { Kemampuan } \\
\text { Kerja }\left(\mathrm{X}_{2}\right)\end{array}$ & 0,896 & 0,444 & Reliabel \\
\hline $\begin{array}{c}\text { Kinerja } \\
\text { Pegawai (Y) }\end{array}$ & 0,890 & 0,444 & Reliabel \\
\hline Sumber : Data Olahan $(2018)$ &
\end{tabular}

Dari tabel diatas diketahui hasil uji reliabiltas diatas dapat dilihat bahwa nilai Cronbach's Alpha Variabel Komunikasi $\left(\mathrm{X}_{1}\right)$ adalah sebesar 0,885 . Nilai $r_{\text {tabel }}$ dengan $\mathrm{n}=$ $20, \alpha=5 \%$ adalah sebesar 0,444 . Hal ini berarti item - item pertanyaan pada variabel komunikasi $\left(\mathrm{X}_{1}\right)$ tersebut reliabel dan dapat dijadikan sebagai alat ukur pada analisis selanjutnya.

Hasil uji reabilitas nilai Cronbach's Alpha variabel kemampuan kerja $\left(\mathrm{X}_{2}\right)$ adalah sebesar 0,896 . Nilai $r_{\text {tabel }}$ dengan $n=20, \alpha=5 \%$ adalah sebesar 0,444. Hal ini berarti item - item pertanyaan pada variabel kemampuan kerja $\left(\mathrm{X}_{2}\right)$ tersebut reliabel dan dapat dijadikan sebagai alat ukur pada analisis selanjutnya.

Hasil uji reabilitas nilai Cronbach's Alpha variabel Kinerja Pegawai (Y) adalah sebesar 0,890. Nilai $r_{\text {tabel }}$ dengan $n=20, \alpha=5 \%$ adalah sebesar 0,444. Hal ini berarti item item pertanyaan pada variabel Kinerja Pegawai (Y) tersebut reliabel dan dapat dijadikan sebagai alat ukur pada analisis selanjutnya.

\section{Hasil Uji Regresi Linier Berganda \\ Tabel 5 \\ Hasil Analisis Regresi Linier \\ Berganda}

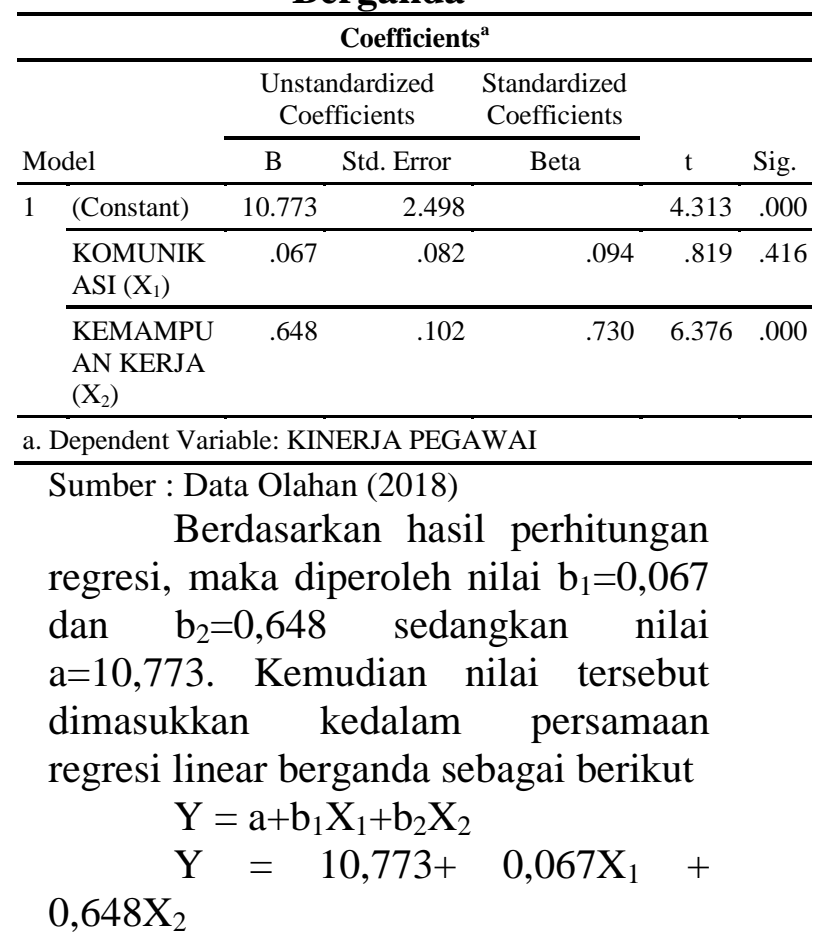

Arti persamaan tersebut adalah :

1. Nilai konstanta sebesar $\mathrm{a}=10,773$ menyatakan bahwa jika komunikasi dan kemampuan kerja tidak ada perubahan atau nilainya nol maka nilai variabel kinerja pegawai adalah sebesar 10,773.

2. Koefisien regresi komunikasi sebesar $b_{1}=0,067$ menyatakan bahwa setiap peningkatan komunikasi sebesar satu satuan maka hal tersebut akan meningkatkan kinerja pegawai sebesar 0,067.

3. Koefisien regresi kemampuan kerja sebesar $b_{2}=0,648$ menyatakan bahwa setiap peningkatan kemampuan kerja sebesar satu satuan maka hal tersebut akan meningkatkan kinerja pegawai sebesar 0,648. 


\begin{abstract}
Hasil Uji Koefisien Determinasi $\left(\mathbf{R}^{2}\right)$ Tabel 6

Hasil Analisis Regresi Determinan

$\left(\mathbf{R}^{2}\right)$

Model Summary

\begin{tabular}{lcccr}
\hline \multicolumn{4}{c}{ Model Summary } \\
\hline Model & $\mathrm{R}$ & $\begin{array}{c}\text { R } \\
\text { Square }\end{array}$ & $\begin{array}{c}\text { Adjusted R } \\
\text { Square }\end{array}$ & $\begin{array}{c}\text { Std. Error of } \\
\text { the Estimate }\end{array}$ \\
\hline 1 & $\begin{array}{r}\text {. } \\
\text { a }\end{array}$ & .649 & .639 & 2.376
\end{tabular}

a.Predictors: (Constant), KEMAMPUAN KERJA, KOMUNIKASI

Sumber : Data Olahan (2018)

Dari tabel diatas diperoleh angka $\mathrm{R}^{2}$ sebesar 0,649 atau $64,9 \%$. Nilai tersebut memberi pengertian bahwa Komunikasi $\left(\mathrm{X}_{1}\right)$ dan Kemampuan Kerja $\left(\mathrm{X}_{2}\right)$ memberikan sumbangan pengaruh sebesar 0,649 terhadap Kinerja Pegawai (Y). Sedangkan sisanya sebesar $35,1 \%$ dipengaruhi oleh variabel yang lain yang tidak masuk dalam penelitian ini seperti kedisiplinan, semangat kerja, motivasi, dll.
\end{abstract}

\section{Hasil Uji F}

Dari analisa output regresi dapat diketahui nilai $\mathrm{F}$ seperti tabel berikut :

Tabel 7

Hasil Uji F

\begin{tabular}{|c|c|c|c|c|c|c|}
\hline \multicolumn{7}{|c|}{ ANOVA $^{b}$} \\
\hline \multicolumn{2}{|c|}{ Model } & $\begin{array}{l}\text { Sum of } \\
\text { Squares }\end{array}$ & Df & $\begin{array}{l}\text { Mean } \\
\text { Square }\end{array}$ & F & Sig. \\
\hline \multirow[t]{3}{*}{1} & Regression & 731.914 & 2 & 365.957 & 64.841 & $.000^{\mathrm{a}}$ \\
\hline & Residual & 395.073 & 70 & 5.644 & & \\
\hline & Total & 1126.986 & 72 & & & \\
\hline
\end{tabular}

a. Predictors: (Constant), KEMAMPUAN KERJA, KOMUNIKASI

b. Dependent Variable: KINERJA PEGAWAI

Sumber : Data Olahan (2018)

Dengan menggunakan tingkat keyakinan 95\%, a=5\%, df1 (jumlah variabel-1)=2 dan df2 (n-k-1)atau(73$2-1)=70$. Nilai $F_{\text {hitung }}$ adalah sebesar 64,841 dengan tingkat signifikansi
0,000. Menurut Sugiyono (2014:295) jika $F_{\text {hitung }}>F_{\text {tabel }}$ maka Ho ditolak dan Ha diterima. Sebaliknya jika $F_{\text {hitung }}<$ $F_{\text {tabel }}$ maka Ho diterima dan Ha ditolak. Pada penelitian ini ternyata $F_{\text {hitung }}$ $\left(64,841>F_{\text {tabel }}(3,13)\right.$, artinya Ho ditolak dan $\mathrm{Ha}$ diterima. Hal ini menunjukkan ada pengaruh yang signifikan antara komunikasi dan kemampuan kerja terhadap kinerja pegawai.

Berdasarkan deskripsi di atas secara nyata dapat disimpulkan bahwa terdapat hubungan positif antara komunikasi dan kemampuan kerja dengan kinerja pegawai Pada Dinas Tanaman Pangan, Perkebunan dan Kehutanan Kota Lubuklinggau. Artinya semakin tinggi angka skor untuk komunikasi dan kemampuan kerja, semakin tinggi juga tingkat kinerja pegawai.

Dari persamaan regresi $\mathrm{Y}=$ $10,773+0,067 \mathrm{X}_{1}+0,648 \mathrm{X}_{2}$ menggunakan nilai konstanta sebesar a $=10,773$ yang artinya bahwa jika nilai koefisien regresi komunikasi dan kemampuan kerja tidak ada perubahan atau nilainya nol maka nilai kinerja pegawai adalah sebesar 10,773.

Nilai koefisien regresi yang dihasilkan variabel komunikasi sebesar $\mathrm{b}=0,067$ menyatakan bahwa setiap peningkatan komunikasi sebesar satu satuan maka hal tersebut akan meningkatkan kinerja pegawai sebesar 0,067. Demikian juga sebaliknya jika ada penurunan komunikasi sebesar satu satuan maka akan menurunkan kinerja pegawai sebesar 0,067 .

Nilai koefisien regresi yang dihasilkan variabel Koefisien regresi kemampuan kerja sebesar b2 $=0,648$ menyatakan bahwa setiap peningkatan kemampuan kerja sebesar satu satuan maka hal tersebut akan meningkatkan kinerja pegawai sebesar 0,648. Demikian juga sebaliknya jika ada 
penurunan kemampuan kerja sebesar satu satuan maka akan menurunkan kinerja pegawai sebesar 0,648.

Nilai koefisien determinasi atau $\mathrm{R}$ square $\left(\mathrm{R}^{2}\right)$ sebesar 0,649 . Hal ini menunjukkan bahwa variabel komunikasi dan kemampuan kerja secara bersama - sama memberikan kontribusi terhadap kinerja pegawai sebesar 0,649. Hal ini menunjukkan bahwa variabel komunikasi dan kemampuan kerja secara bersama sama memberi kontribusi terhadap variabel kinerja pegawai sebesar 64,9\% dan setelah disesuaikan nilai sisanya sebesar $35,1 \%$ yang tidak termasuk dalam penelitian ini seperti kedisiplinan, semangat kerja, motivasi, dll.

Dengan menggunakan tingkat keyakinan 95\%, a=5\%, df1 (jumlah variabel-1)=2 dan df2 (n-k-1)atau(73$2-1)=70$. Nilai $F_{\text {hitung }}$ adalah sebesar 64,841 dengan tingkat signifikansi 0,000. Menurut Sugiyono (2014, h.259) jika $F_{\text {hitung }}>F_{\text {tabel }}$ maka Ho ditolak dan Ha diterima. Sebaliknya jika $F_{\text {hitung }}<F_{\text {tabel }}$ maka Ho diterima dan Ha ditolak. Pada penelitian ini ternyata $F_{\text {hitung }}(64,841)>F_{\text {tabel }}(3,13)$, artinya Ho ditolak dan $\mathrm{Ha}$ diterima. Hal ini menunjukkan ada pengaruh yang signifikan antara komunikasi dan kemampuan kerja terhadap kinerja pegawai.

Komunikasi adalah proses penyampaian dan pertukaran informaasi sekurang-kurangnya antara dua pihak yang berperan sebagai pengirim (sender) dan penerima (receiver) dengan menggunakan berbagai media yang ada (Daryanto,2013).

Pengaruh variabel komunikasi lebih kecil dibandingkan dengan pengaruh variabel kemampuan kerja. Hal ini terjadi karena kinerja pegawai pada Dinas Tanaman Pangan,
Perkebunan dan Kehutanan KotaLubuklinggau kemampuan kerja lebih diutamakan agar mencapai hasil kinerja yang lebih baik.

Kemampuan seorang individu untuk terus menjalankan usaha dalam menjalaniberbagai macam tugas hingga berhasil yang bisa dikerjakan oleh seseorang. Keseluruhan kemampuan individual personil pada hakikatnya dibentuk oleh sifat-sifat dan kemampuan-kemampuan yang dikemukakan oleh Winardi (2007) bahwa salah satu akibat langsung dari sifat kemampuan yang harus dimiliki oleh setiap organisator harus terus memupuk "inisiatif".

Kinerja merupakan hasil yang mempunyai hubungan kuat dengan tujuan strategis organisasi, kepuasan konsumen dan memberikan kontribusi ekonomi. Lebih jauh Indra Bastian menyatakan bahwa kinerja adalah gambaran mengenai tingkat pencapaian pelaksanaan suatu kegiatan /program/kebijaksanaan dalam mewujudkan sasaran, tujuan, misi dan visi organisasi yang tertuang dalam perumusan skema strategis (strategic planning) suatu organisasi (Fahmi, 2011:2).

\section{PENUTUP}

\section{Kesimpulan}

Berdasarkan penelitian dari hasil analisis sesuai dengan tujuan penelitian, maka peneliti dapat menyimpulkan bahwa :

Hasil perhitungan Anova (Uji F), terlihat bahwa nilai $F_{\text {hitung }}$ adalah sebesar 64,841 dengan tingkat signifikan 0,000 sedangkan $\quad F_{\text {tabel }}$ dengan $\alpha=5 \%$ dan (n-k-1)atau(73-2$1)=70$. Serta pembilang (k-2) adalah sebesar 3,13. F Fitung $(64,841)>F_{\text {tabel }}$ $(3,13)$, artinya Ho ditolak dan $\mathrm{Ha}$ diterima. Hal ini menunjukkan ada pengaruh yang signifikan antara 
komunikasi dan kemampuan kerja terhadap kinerja pegawai pada Dinas Tanaman Pangan, Perkebunan dan Kehutanan Kota Lubuklinggau.

\section{Saran}

Dari hasil penelitian ini diberikan beberapa saran, antara lain :

1. Komunikasi merupakan faktor penting yang harus dilakukan oleh pegawai dalam meningkatkan kinerja. Oleh karena itu hal - hal yang berkaitan dengan usaha peningkatan komunikasi pegawai lebih ditingkatkan lagi agar komunikasi yang terjalin menjadi lebih lancar.

2. Profesionalisme pimpinan dalam berkomunikasi kepada pegawai harus lebih ditingkatkan agar kinerja pegawai menjadi lebih baik.

3. Kemampuan kerja pegawai harus lebih ditingkatkan lagi agar kinerja yang dihasilkan menjadi lebih baik.

\section{DAFTAR PUSTAKA}

Arikunto, Suharsimi, (2006). Prosedur Penelitian. Jakarta : Rineka Cipta.

Daryanto dan Abdullah, (2013). Pengantar Ilmu Manajemen dan Komunikasi. Cetakan Pertama. Jakarta : Penerbit PT. Prestasi Pustaka Karya.

Effendi, Onong U. (2006). Ilmu, Teori dan Filsafat Komunikasi. Bandung. Citra Aditya Bhakti.

Fahmi, Irham, (2011). Manajemen Kinerja. Bandung : Penerbit Alfabeta.

Fahmi, Irham, (2012). Manajemen. Bandung : Penerbit Alfabeta.

Ridwan, (2009). Pengantar Statistika. Jawa Barat: CV. Alfabeta.

Rivai, Veithzal, (2012). Kepemimpinan dan Perilaku Organisasi.Cetakan ke-9. Penerbit : PT. Rajagrafindo Persada.
Sunardi, (2012). Pengaruh

Komunikasi, Budaya Organisasi dan Kemampuan Kerja Terhadap Kinerja Pegawai Negeri Sipil di Bagian Administrasi Pembangunan Sekretariat Daerah Kota Kediri. Jurnal Ilmu Manajemen, REVITALISASI, 1(1)

Sugiyono, (2014). Statistik Untuk Penelitian. Cetakan ke Dua puluh empat. Bandung : Alfabeta.

Untung Sriwidodo \& Agus Budhi H.(2010) melakukan penelitian yang berjudul Pengaruh Kompetensi, Motivasi, Komunikasi dan Kesejahteraan Terhadap Kinerja Pegawai Dinas Pendidikan. Jurnal Manajemen Sumber Daya Manusia. 4(1)

Wibowo, (2012). Manajemen Kinerja. Cetakan Ke Tiga. Jakarta : PT. Raja Grafindo Persada

Winardi, (2007), Manajemen Perilaku Organisasi, Edisi Revisi, Jakarta, Kencana Prenada Media Group. 